\title{
Ureolytic Activity of the Washed Cell Suspension of Rumen Ciliate Protozoa
}

\author{
Ryoji OnODERA, Yasuko Nakagawa and Makoto Kandatsu* \\ Department of Agricultural Chemistry, Miyazaki University, Miyazaki, Japan \\ * Azabu Veterinary College, Fuchinobe, Sagamihara-shi, Japan
}

Received June 3, 1977

\begin{abstract}
Ureolytic activity of rumen ciliate protozoa was examined in comparison with that of rumen bacteria. Freshly obtained rumen ciliates which were washed five times with B-9 buffer solution previously, decomposed $1.3 \mu \mathrm{mole} / \mathrm{ml}$ of urea to give ammonia after incubation for $6 \mathrm{hr}$ in the buffer solution containing streptomycin, while rumen bacterial suspension decomposed $84.6 \sim 97.8 \mu \mathrm{mole} / \mathrm{ml}$ of urea after incubation for $2 \mathrm{hr}$. The amount of ammonia-N/bacteria-N produced from urea by the suspension of rumen bacteria was usually higher than that by the coexistent suspension consisting of rumen bacteria and ciliates. When the freshly obtained rumen ciliates were previously incubated in the buffer solution containing $100 \mu \mathrm{g} / \mathrm{ml}$ each of streptomycin, penicillin and chloramphenicol (starved ciliates), ureolytic activity of the ciliates decreased with the incubation time and reached zero after $24 \mathrm{hr}$ of incubation. ${ }^{14} \mathrm{C}$-Urea remained unchanged in the medium of the starved ciliates even after incubation for $6 \mathrm{hr}$. All these results led us to the conclusion that rumen ciliate protozoa did not have ureolytic activity and that ureolytic activity of the freshly obtained ciliates might be due to contaminating bacteria.
\end{abstract}

Whether rumen ciliate protozoa decompose urea, which is known to be used as a nitogen source for ruminants, may be one of the problems to be dissolved.

Formerly, Kikuchi et al. ${ }^{11}$ have shown the urease activity of washed cell suspension of rumen ciliate protozoa. They did not use any antibiotics, however, to inhibit the bacterial action contaminating the ciliate suspension. Abou Akkada and Howard ${ }^{2}$ have reported later that Entodinium caudatum, previously starved in buffer-chloramphenicol solution for $36 \mathrm{hr}$, did not produce ammonia from urea during $6 \mathrm{hr}$ of incubation in the presence of chloramphenicol. Kandatsu and Takahashi ${ }^{3}$ have reached the conclusion similar to that of Abou Akkada and Howard ${ }^{2 y}$ by incubating the mixed rumen ciliates, which were not starved in advance, in the absence of antibiotic for $2 \mathrm{hr}$. Naga and El-Shazly ${ }^{4}$ have similarly denied the ureolytic activity of Eudiplodinium medium which was not starved previously but incubated with chloramphenicol. Lately, Onodera et al. ${ }^{5)}$ have shown that L-arginine$\mathrm{U}-{ }^{14} \mathrm{C}$ was degraded to give radioactive orni- thine together with a large amount of ${ }^{14} \mathrm{CO}_{2}$ by washed suspension of freshly obtained mixed rumen ciliates after incubation with streptomycin for $6 \mathrm{hr}$ and have suggested that ${ }^{14} \mathrm{CO}_{2}$ might be produced from radioactive urea liberated from arginine added.

These results could not lead us to the clear conclusion that rumen ciliates did not have ureolytic activity, because the experimental conditions in which they ${ }^{2 \sim 4}$ denied the ureolytic activity in the ciliates were different. Furthermore, there was a disagreement between the results of Naga and El-Shazly ${ }^{4}$ and those of Onodera et al. ${ }^{5}$ in spite of their almost similar experimental conditions using not starved but only washed protozoa in the presence of antibiotics.

Considering these problems, the aim of the present study is to reinvestigate and clarify whether or not rumen ciliates have an ureolytic activity.

\section{MATERIALS AND METHODS}

1. Isolation of rumen ciliate protozoa

Mixed rumen ciliates were obtained by the method 
based on those described in our previous paper ${ }^{8)}$ from a goat (female, body wt.: $42 \mathrm{~kg}$ ) maintained on daily rations consisting of $2 \sim 4 \mathrm{~kg}$ of fresh grass and $200 \mathrm{~g}$ of mixed concentrates. Ophryoscolecid ciliates (expressed as Ophryoscolecidae in Table III) were obtained after incubation of the mixed ciliates in $1.2 \%$ D-mannose solution") (partially modified B-9 buffer solution ${ }^{9)}$ ) at $39^{\circ} \mathrm{C}$ for $5 \mathrm{hr}$ to kill isotrichid ciliates. Mixed ciliates (II) shown in Table III were obtained after incubation at $39^{\circ} \mathrm{C}$ for $5 \mathrm{hr}$ in B-9 buffer solution alone and washing five times with the buffer solution.

\section{Preparation of mixed rumen bacterial suspension}

Mixed rumen bacterial suspension was prepared by the centrifugal method described in the previous paper ${ }^{\text {g) }}$ from the rumen contents of the same goat as mentioned above.

3. Preparation of "coexistent system" consisting of mixed rumen bacteria and mixed rumen ciliates

Rumen contents obtained through the rumen fistula of the goat mentioned above were strained by four layers of surgical gauze and the filtrate was incubated in the separating funnel at $39^{\circ} \mathrm{C}$ for about $60 \mathrm{~min}$ after replacing the air phase of the funnel with nitrogen gas. Fine food debris floated to the upper phase of the filtrate during incubation. The lower liquid phase which was chiefly consisting of bacteria and ciliate protozoa with probably a small number of other microorganisms such as fungi ${ }^{10,11)}$ was used as "coexistent system."

\section{Preparation of rumen fluid}

The lower liquid phase just mentioned in 3. was centrifuged at $27,000 \times g$ for $30 \mathrm{~min}$ and the supernatant fluid was supplied for the test as rumen fluid.

\section{Cultural methods and treatment of samples \\ 1) In the case of non-radioactive urea added to the medium}

a) Ciliate suspension and their homogenate. Ten $\mathrm{ml}$ of ciliate suspension (ciliate concentration: $4 \%$ $(v / v)$ in B-9 buffer solution $\left.{ }^{8}\right)$ or $10 \mathrm{ml}$ of homogenate of ciliates, which were obtained after breaking down one $\mathrm{ml}$ of the living ciliates in $24 \mathrm{ml}$ of $\mathrm{B}-9$ buffer solution below $7^{\circ} \mathrm{C}$ for $20 \mathrm{~min}$ by an Ultrasonic Generator (Model: T-A-4201, Kaijo Denki Co., Ltd., Japan), were incubated with or without $10 \mu \mathrm{mole} / \mathrm{ml}$ of urea and with $100 \mu \mathrm{g} / \mathrm{ml}$ of streptomycin sulfate alone or with $100 \mu \mathrm{g} / \mathrm{ml}$ each of the mixture of streptomycin sulfate, penicillin $\mathrm{G}$ potassium and chloramphenicol sodium succinate at $39^{\circ} \mathrm{C}$ for 3 or $6 \mathrm{hr}$. Before and after incubation, $0.5 \mathrm{ml}$ of the medium was immediately taken out with stirring and supplied for determination of ammonia produced, b) Bacterial suspension and coexistent system. Ten $\mathrm{ml}$ of each suspension were incubated with or without $100 \mu \mathrm{mole} / \mathrm{ml}$ of urea except for the case of Table I, in which case $10 \mu \mathrm{mole} / \mathrm{ml}$ of urea were added, at $39^{\circ} \mathrm{C}$ for indicated hours in each Table. Before and after incubation, $0.1 \mathrm{ml}$ of the medium was sampled with stirring and submitted to the determination of ammonia.

\section{2) In the case of ${ }^{14} \mathrm{C}$-urea added to the medium}

In this case, were used starved ciliates which were obtained after incubation of $2 \mathrm{ml}$ of freshly isolated mixed rumen ciliates in $50 \mathrm{ml}$ of B-9 buffer solution containing $100 \mu \mathrm{g} / \mathrm{ml}$ each of streptomycin sulfate, penicillin $\mathrm{G}$ potassium and chloramphenicol sodium succinate at $39^{\circ} \mathrm{C}$ for $24 \mathrm{hr}$. The same amount of each of the three kinds of antiboitics was added again to the medium after $12 \mathrm{hr}$ of incubation. Eight $\mathrm{ml}$ of the suspension of the starved rumen ciliates in B-9 buffer solution were transferred to $30 \mathrm{ml}$ of conical flask, to which $80 \mu \mathrm{mole} / \mathrm{ml}$ of ${ }^{12} \mathrm{C}$-urea, $10 \mu \mathrm{Ci}$ of ${ }^{14} \mathrm{C}$-urea and the mixture of the three kinds of antibiotics mentioned above $(800 \mu \mathrm{g}$ each) were previously added, and shaken for a few minutes to dissolve them. Four $\mathrm{ml}$ of the suspension containing urea and antibiotics were immediately transferred into a Warburg flask with a center well to which about $0.7 \mathrm{ml}$ of $20 \%$ $\mathrm{KOH}$ was added previously to trap carbon dioxide. As soon as the air phase of the Warburg flask was replaced with nitrogen gas, the flask was sealed and incubated at $39^{\circ} \mathrm{C}$ for $6 \mathrm{hr}$. After incubation, microbial activity was stopped by adding one $\mathrm{ml}$ of $50 \%$ trichloroacetic acid (TCA) into the medium and the flask was left overnight at room temperature. The remaining starved ciliate suspension $(4 \mathrm{ml})$ was similarly transferred into another Warburg flask as completely as possible and immediately subjected to addition of one $\mathrm{ml}$ of $50 \%$ TCA to make the zero-time control. Five $\mu 1$ of sample were taken out for the determination of total radioactivity.

Raioactivities in carbon dioxide, ciliates and some components (shown in Table IV) of the supernatant medium were determined by the same manners as those described in 2. $a$ ) of the Materials AND Metrods of the previous paper ${ }^{2)}$ with some modifications that centrifugation to get ciliate fraction was carried out at $120 \times g$ for $30 \mathrm{sec}$ in this case instead of $27,000 \times g$ for $30 \mathrm{~min}$ in the previous case ${ }^{9)}$ and that the desalting of the water-soluble fraction of the supernatant fluid was made as follows: The water-soluble fraction after extraction with ether under alkaline condition was concentrated to about $5 \mathrm{ml}$ and desalted at first by percolation through a bed $(2 \mathrm{~cm} \times 6 \mathrm{~cm})$ of 'Amberlite' $\mathrm{CG}-120$ ( $\mathrm{H}$ form) resin. After washing the bed with about $1000 \mathrm{ml}$ of water, the washings were concentrated in vacuo to about $50 \mathrm{ml}$, poured again into an another column $(2.5 \mathrm{~cm} \times 15 \mathrm{~cm})$ of 
'Amberlite' CG-400 (OH form) resin and washed with about $1500 \mathrm{ml}$ of water. The washings thus obtained were evaporated and used for the determination of radioactivity and for paper chromatography. The fraction containing amino acids adsorbed in the bed of 'Amberlite' CG-120 resin was eluted with $300 \mathrm{ml}$ of $2 \mathrm{~N} \mathrm{NH}{ }_{4} \mathrm{OH}$. The eluate (Eluate-120) was taken to dryness and used for the determination of radioactivity. The substances adsorbed on 'Amberlite' CG-400 resin were eluted with $500 \mathrm{ml}$ of $2 \mathrm{~N} \mathrm{HCl}$. The eluate (Eluate-400) was concentrated to $10 \mathrm{ml}$ and radioactivity was determined.

\section{Analytical method}

Urease activity was determined by the amount of ammonia- $\mathrm{N}$ liberated from urea by rumen microorganisms and expressed as a molar amount of decomposed urea.

Ammonia- $\mathrm{N}$ was determined by Conway's microdiffusion method. ${ }^{12)}$

Bacterial nitrogen was determined by micro Kjeldahl method after treating the samples as follows; 1). Bacterial nitrogen of the mixed rumen bacterial suspension: Firstly $1 \mathrm{ml}$ of the mixed rumen bacterial suspension mentioned in 2 . was supplied for wet ashing and the nitrogen contant (A) was determined. Secondly about $5 \mathrm{ml}$ of the same suspension were centrifuged at $27,000 \times \mathrm{g}$ for $30 \mathrm{~min}$ and one $\mathrm{ml}$ of the supernatant fluid was taken out to determine the nitrogen content (B). The difference between $\mathbf{A}$ and $\mathbf{B}$ was conveniently thought as the bacterial nitrogen. 2). Bacterial nitrogen of the "coexistent system": About $10 \mathrm{ml}$ of the microbial suspension of the "coexistent system" shown in 3 . were centrifuged at $120 \times g$ for $30 \mathrm{sec}$ to remove ciliate protozoa from the suspension and $1 \mathrm{ml}$ of the supernatant fluid was supplied for determination of nitrogen content (A). The remaining supernatant fluid which still contained microorganisms such as bacteria was centrifuged again at $27,000 \times g$ for $30 \mathrm{~min}$ and $1 \mathrm{ml}$ of the supernatant fluid was taken out to determine the nitrogen content (B). The difference between $\mathbf{A}$ and $\mathbf{B}$ was conveniently thought as the bacterial nitrogen of the "coexistent system."

Paper chromatography, autoradiography and the determination of radioactivity were carried out by quite the same methods as those of our previous paper. ${ }^{\text {g) }}$

\section{Chemicals}

Urea was supplied by Wako Pure Chemical Industries, Ltd. Streptomycin sulfate, penicillin G potassium and chloramphenicol sodium succinate were supplied by Meiji Seika Kaisha, Ltd., Banyu Pharmacentical Co., Ltd., and Sankyo Co., Ltd., respectively. ${ }^{14} \mathrm{C}$-Urea (Sp. Act.: $50.0 \mathrm{mCi} / \mathrm{mm}$ ) was supplied by
Daiichi Pure Chemicals Co., Ltd.

\section{RESULTS AND DISCUSSION}

At the beginning, ureolytic activity of the washed cell suspension of freshly obtained rumen ciliate protozoa was examined in the medium containing $10 \mu \mathrm{mole} / \mathrm{ml}$ of urea and $100 \mu \mathrm{g} / \mathrm{ml}$ of streptomycin sulfate. After incubation for $6 \mathrm{hr}, 13 \%$ of added urea were decomposed to give ammonia by the ciliates (Table I). Results of trials over five times showed almost similar activity. Thereafter, ureolytic activity of ciliates was compared with those of bacteria, coexistent system of bacteria and ciliates and rumen fluid alone. As shown in Table I, rumen fluid was shown to be slightly ureolytic, while rumen bacterial suspension and coexistent system decomposed almost all urea added.

\section{Table I. UReolytic Activities of Rumen MicroorganismS AND RUMEN FLUID}

These values were obtained after incubation with $10 \mu \mathrm{mole} / \mathrm{ml}$ of urea for $6 \mathrm{hr}$.

\begin{tabular}{lc}
\hline $\begin{array}{l}\text { Ancubation } \\
\text { system }\end{array}$ & $\begin{array}{c}\text { Decompd. urea } \\
\mu \text { mole/mity }\end{array}$ \\
\hline Ciliates $^{(2)}$ & 1.3 \\
Bacteria $^{b}$ & 10.5 \\
Coexistence $^{(s)}$ & 9.1 \\
Rumen fluid $^{d)}$ & 0.06 \\
\hline
\end{tabular}

Ciliate composition in these expt. Entodiniinae, Diplodiniinae, Isotricha, Dasytricha

a) $\begin{array}{llll}162 & 13 & 5 & 25 \times 10^{3} / \mathrm{ml}\end{array}$

b) $1104 \quad 15 \quad 3 \quad 34 \%$

b) The word 'Bacteria' used here means rumen microorganisms except for ciliate protozoa.

c) Coexistence: Coexistent system of ciliates and bacteria.

d) Supernatant fluid after centrifugation of rumen juice at $27,000 \times g$ for $30 \mathrm{~min}$.

As it was impossible to compare the difference of ureolytic activities between ciliates and bacteria from these results, ureolytic activity of the bacterial suspension was further examined by increasing the amount of urea to be added to $100 \mu \mathrm{mole} / \mathrm{ml}$. From the results shown in Table II, most of all urea added 
Table II. Ureolytic Actrvities of Rumen Microorganisms

These values were obtained after incubation with $100 \mu$ mole $/ \mathrm{ml}$ of urea.

\begin{tabular}{|c|c|c|c|c|c|c|c|c|c|}
\hline \multirow{2}{*}{\multicolumn{2}{|c|}{$\begin{array}{l}\text { Incubation time, hr } \\
\text { Decompd. urea } \\
\text { Incubation system }\end{array}$}} & \multicolumn{2}{|c|}{0.5} & \multicolumn{2}{|c|}{1} & \multicolumn{2}{|c|}{2} & \multicolumn{2}{|c|}{3} \\
\hline & & $\begin{array}{c}\mu \mathrm{mole} / \\
\mathrm{ml}\end{array}$ & $\begin{array}{l}\text { umole/ } \\
\operatorname{mgNa}\end{array}$ & $\underset{\mathrm{ml}}{\mu \mathrm{mole} /}$ & $\begin{array}{l}\mu \mathrm{mole} / \\
\mathrm{mgN}^{a} /\end{array}$ & $\begin{array}{c}\mu \mathrm{mole} / \\
\mathrm{ml}\end{array}$ & $\begin{array}{l}\mu \mathrm{mole} \\
\mathrm{mgN}^{a}\end{array}$ & $\underset{\mathrm{ml}}{\mu \mathrm{mole} /}$ & $\begin{array}{l}\mu \mathrm{mole} / \\
\mathrm{mgN}^{a}\end{array}$ \\
\hline Bacteria & 1 & 34.6 & 54.9 & 54.8 & 87.0 & 84.6 & 134.3 & 94.4 & 149.8 \\
\hline & 2 & - & $\rightarrow$ & - & - & 97.8 & 128.9 & 一 & - \\
\hline \multirow[t]{2}{*}{ Coexistence $^{b)}$} & 1 & 一 & - & - & - & 77.8 & 89.6 & 一 & 一 \\
\hline & 2 & - & - & - & - & 96.9 & 100.9 & - & 一 \\
\hline
\end{tabular}

a) Bacterial nitrogen.

b) Coexistent system of ciliates and bacteria. Ciliate composition in these expt.

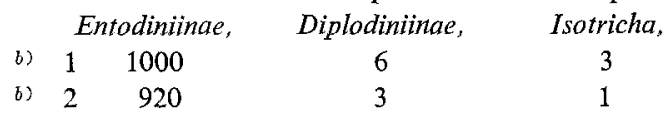

$\begin{array}{cl}\text { Dasytricha } & \\ 13 & \times 10^{3} / \mathrm{ml} \\ 2 & \times 10^{3} / \mathrm{ml}\end{array}$

was known to be deomposed during incubation for $3 \mathrm{hr}$ by the rumen bacteria. These values, therefore, made us presume at first that ureolytic activity of rumen bacteria might be much larger than that of rumen ciliates, even if the ciliates really had urease. By the way, it is interesting that the amount of urea decomposed by bacteria usually showed higher value than that by coexistent system of bacteria and ciliates. In this regard, it was assumed that rumen ciliates might produce some valuable compounds with which rumen bacteria could synthesize amino acids and further their body protein by using ammonia liberated from urea and/or that rumen ciliates might be able to utilize ammonia for the synthesis of some amino acids such as citrulline, arginine, glutamine and so on.

Then ureolytic activity of rumen ciliates was further examined. It was firstly tested whether or not there were differences of ureolytic activities between mixed ciliates and ophryoscolecid ciliates. In this test, mixed ciliates, which had previously been incubated in B-9 buffer solution for $5 \mathrm{hr}$ and washed five times with the buffer solution (starved ciliates), were used simultaneously as well as the freshly obtained ciliates. From the results of Table III, though there apparently seemed to be difference between freshly obtained ciliates and ophryoscolecid ciliates, no true difference was presumed to exist between the two, because the value for starved ciliates was almost equal to that for ophryoscolecid ciliates. Ureolytic activity of homogenate of ciliates was $3.5 \sim 4.6$ fold higher than that of intact cells, but there was no difference between the activity of homogenate of strarved ciliates and that of ophryoscolecid ciliates, in agreement with the result of intact cells. In this experiment, it seemed to be rather strange that the ureolytic activity of the starved ciliates (both mixed and ophryoscolecid ciliates) fell off to the level less than a half of that of freshly obtained ciliates in the cases of not only intact cells but also homogenates. These results made us infer that ureolytic activity of rumen ciliates which was apparently seemed to be of ciliates themselves might be of mingled rumen bacteria which might probably survive outside and/or inside ciliate bodies in spite of five-times-washing of the ciliates, because the ureolytic activity of rumen bacteria was much higher beyond comparison (Table II), in contrust to their activity of metabolism of amino acids such as lysine. ${ }^{9}$ )

In the next experiment, the relation of ureolytic activity of rumen ciliates to starved time was examined and the result was shown in Fig. 1. Ureolytic activity of the ciliates declined with increasing of starved time and reached zero after $24 \mathrm{hr}$ of incubation though the ciliates were microscopically confirmed to be still surviving and retaining their motilities. 
TABLE III. UREOLYTIC ACTIVITIES OF RUMEN Cillates and Their Homogenates

These values were obtained after incubation with $10 \mu \mathrm{mole} / \mathrm{ml}$ of urea for $6 \mathrm{hr}$.

\begin{tabular}{|c|c|c|}
\hline $\begin{array}{l}\text { Decompd. } \\
\text { urea }\end{array}$ & $\begin{array}{l}\text { Intact cells } \\
\mu \mathrm{mole} / \mathrm{ml}\end{array}$ & $\begin{array}{c}\text { Homogenates } \\
\mu \mathrm{mole} / \mathrm{ml}\end{array}$ \\
\hline Mixed ciliates $(\mathbf{I})^{a}$ & 2.0 & 9.1 \\
\hline Mixed ciliates(II) ${ }^{b}$ & 0.9 & 3.5 \\
\hline Ophryoscolecidae & 1.0 & 3.4 \\
\hline
\end{tabular}

a) Washed rumen ciliates freshly obtained were immediately used.

b) Mixed ciliates after incubation for $5 \mathrm{hr}$ in $\mathrm{B}-9$ buffer solution with streptomycin sulfate and washing (starved ciliates) were used.

c) Ophryoscolecidae were obtained after incubation for $5 \mathrm{hr}$ in $1.2 \%$ mannose solution to kill Isotrichidae.

Ciliate composition in these expt. Entodiniinae, Diplodiniinae, Dasytricha

$\begin{array}{lllcc}\text { a) } & 486 & 23 & 8 & \times 10^{3} / \mathrm{ml} \\ \text { c) } & 468 & 25 & 9 & " \prime\end{array}$

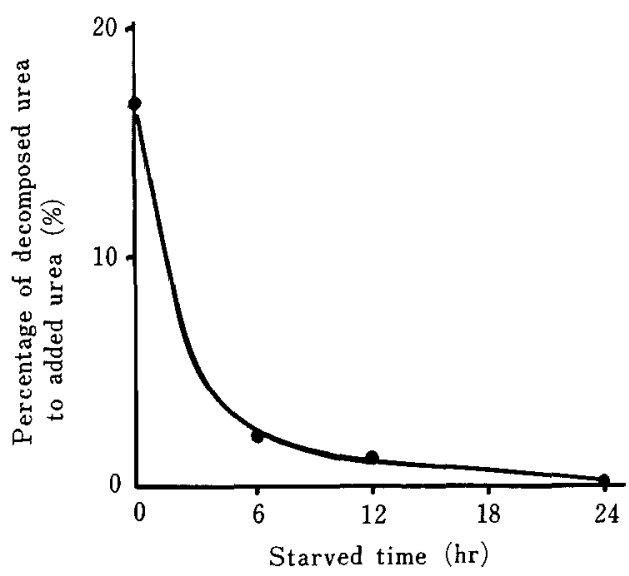

FIG. 1. Relation between the Ureolytic Activity of Rumen Ciliates and the Starved Time.

of incubation. This assumption has, in fact, been demonstrated and the results will be published later. ${ }^{13)}$

To certify the fact that rumen ciliates have

Table IV. Fate of ${ }^{14}$ C-Urea in the Medium of Starved Rumen Cillates

\begin{tabular}{|c|c|c|c|c|}
\hline \multirow{2}{*}{$\begin{array}{l}\text { Incubation time, } \mathrm{hr} \\
\text { Fractions }\end{array}$} & \multicolumn{2}{|c|}{0} & \multicolumn{2}{|c|}{6} \\
\hline & $\begin{array}{c}\text { Radioactivity } \\
\text { (cpm/ml) }\end{array}$ & $\begin{array}{c}\text { Percentage } \\
(\%)\end{array}$ & $\begin{array}{c}\text { Radioactivity } \\
(\mathrm{cpm} / \mathrm{ml})\end{array}$ & $\begin{array}{c}\text { Percentage } \\
(\%)\end{array}$ \\
\hline Before incubation & & & & \\
\hline $\begin{array}{l}\text { Total } \\
\quad \text { After incubation }\end{array}$ & $2,268,590$ & 100 & $2,268,590$ & 100 \\
\hline Carbon dioxide & 9,510 & 0.4 & 10,103 & 0.5 \\
\hline$E F 1^{a)}$ & 19,398 & 0.9 & 24,476 & 1.1 \\
\hline$E F 2^{b)}$ & 17,362 & 0.8 & 20,493 & 0.9 \\
\hline Washings $^{c}$ ) & $2,188,590$ & 96.5 & $2,182,187$ & 96.2 \\
\hline Urea in washings $\left.{ }^{\circ}\right)$ & $2,157,870$ & 95.1 & $2,158,500$ & 95.1 \\
\hline $\mathrm{X}_{1}$ in washings ${ }^{c}$ ) & 24,500 & 1.1 & 23,450 & 1.0 \\
\hline Eluate-120d) & 22,656 & 1.0 & 23,906 & 1.1 \\
\hline Ciliates & 1,148 & 0.05 & 1,113 & 0.05 \\
\hline
\end{tabular}

a) EF1: Ether-soluble fraction under an acidic condition.

b) EF2: Ether-soluble fraction under an alkaline condition.

o) Washings: Water effluent at desalting by anion-exchange resin of the first water effluent at desalting of the supernatant fluid of the medium by cation-exchange resin.

d) Supernatant fluid of the medium desalted by cation-exchange resin.

Composition of ciliates in this expt.

Entodiniinae, Diplodiniinae, Dasytricha

$1050 \quad 1 \quad 2 \times 10^{3} / \mathrm{ml}$

From this fact, rumen ciliates seemed to have really no ureolytic activity and the mingled bacteria were assumed to be completely killed and/or digested by the ciliates during $24 \mathrm{hr}$ no ureolytic activity, mixed ciliates starved for $24 \mathrm{hr}$ were incubated with ${ }^{14} \mathrm{C}$-urea for $6 \mathrm{hr}$. As shown in Table IV, there was no difference of radioactivity of each fraction between 
before and after incubation. Most of the radioactivity was found in washings i.e. final water effluent at desalting by anion-exchange resin of the first water effluent at desalting of the supernatant fluid of the medium by cation-exchange resin (Table IV) and almost all radioactivity of this fraction was revealed to occur in urea by paper chromatography and autoradiography (Fig. 2). In this regard,

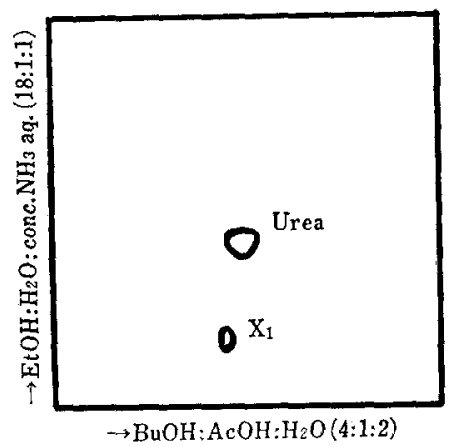

FIG. 2. Autoradiogram of the Paper Chromatogram of Washings (Shown in Table IV) at Desalting of the Supernatant Fluid of the Medium after Incubation of Starved Ciliates with ${ }^{14} \mathrm{C}$-Urea for $6 \mathrm{hr}$.

urea had been known not to adsorb on both cation- and anion-exchange resins by our preliminary experiment. The spot of urea on the paper chromatogram was detected as cleaner white one compared with surroundings after spraying of ninhydrin solution and heating at $80 \sim 100^{\circ} \mathrm{C}$ for $15 \mathrm{~min}$. The autoradiogram of the paper chromatogram of the washings after incubation showed an unidentified spot $\left(\mathrm{X}_{1}\right)$ besides the spot of urea. But the spot $\left(\mathrm{X}_{1}\right)$ was also found on that before incubation, so the spot $\left(\mathrm{X}_{1}\right)$ was not thought to be formed from urea by rumen ciliates. Radioactivities of Eluate-120 and of ciliates were too weak to make a spot in autoradiogram. Thus most of all urea was revealed to remain unchanged in the medium of strarved rumen ciliates even after incubation.

All these results led us to the conclusion that rumen ciliate protozoa did not have ureolytic activity. In connexion with the result of Onodera et al. ${ }^{5)}$ that a large amount of radioactive carbon dioxide had been produced from $\mathrm{L}$-arginine-U- ${ }^{14} \mathrm{C}$ with ornithine by freshly obtained mixed rumen ciliates, it was presumed that radioactive carbon dioxide might be produced by the rumen bacteria mingled in the ciliate suspension from radioactive urea which might be formed from $\mathrm{L}-$ arginine- $\mathrm{U}-{ }^{14} \mathrm{C}$ by probably rumen ciliates because our unpublished data that will be published in the near future revealed an intensive arginase activity of starved $(24 \mathrm{hr})$ rumen ciliates.

Acknowledgement. The authors are grateful to Drs. Hiromitsu Ootsuka and Katsumi Hamana, Miyazaki University, for inserting permanent rumen fistula into a goat.

This work was supported by Radioisotope Laboratory of Miyazaki University.

\section{REFERENCES}

1) E. Kikuchi, M. Soejima, K. Sugawara and K. Shimura, Nippon Nôgeikagaku Kaishi, 32, 917 (1958).

2) A. R. Abou Akkada and B. H. Howard, Biochem. J., 82, 313 (1962).

3) M. Kandatsu and N. Takahashi, Nippon Nôgeikagaku Kaishi, 37, 486 (1963).

4) M. A. Naga and K. El-Shazly, J. Gen. Microbiol., 53, 305 (1968).

5) R. Onodera, W. Tsutsumi and M. Kandatsu, Agric. Biol. Chem., 41, 2169 (1977).

6) Y. Ueda, R. Onodera and M. Kandatsu, Jap. $J$. Zootech. Sci., 46, 34 (1975).

7) R. Onodera, Y. Toyofuka, S. Fujita, S. Nakahara and M. Kandatsu, ibid., 45, 652 (1974).

8) R. Onodera and M. Kandatsu, ibid., 41, 343 (1970).

9) R. Onodera and M. Kandatsu, Agric. Biol. Chem., 39, 1239 (1970).

10) R. J. T. Clarke and M. E. diMenna, J. Gen. Microbiol., 25, 113 (1961).

11) D. Brewer and A. Taylor, ibid., 59, 137 (1969).

12) E. J. Conway, "Microdiffusion Analysis and Volumetric Error," Crosby Lockwood and Son Ltd., London, 1950.

13) R. Onodera, H. Yamaguchi, C. Eguchi and M. Kandatsu, Agric. Biol. Chem., 41, (12), in press. 